Article

\title{
Economic Valuation of Ground Mounted Photovoltaic Systems
}

\author{
Francesca Salvo ${ }^{1, *}$, Marina Ciuna ${ }^{2}$, Manuela De Ruggiero ${ }^{1}$ and Samuele Marchianò ${ }^{1}$ \\ 1 Department of Environmental and Chemical Engineering, University of Calabria, Via Pietro Bucci Cubo 46b, \\ 87036 Rende, Italy; manueladeruggiero@gmail.com (M.D.R.); samuelemarchiano.esn@gmail.com (S.M.) \\ 2 Department of Civil, Environmental, Aerospace, Materials, Engineering, University of Palermo, \\ Viale delle Scienze, Ed. 8, 90128 Palermo, Italy; marina.ciuna@unipa.it \\ * Correspondence: francesca.salvo@unical.it; Tel.: +39-984-496770
}

Received: 10 April 2017; Accepted: 13 June 2017; Published: 16 June 2017

\begin{abstract}
The appraisal of ground mounted photovoltaic systems is an important question, due to increasing investments in renewable energies. The costs related to installation and maintenance, and the economic benefits related to the energy saving, suggests the use of an income approach, in order to consider the financial aspects of the photovoltaic systems. This paper proposes the use of the Discounted Cash Flow Analysis (DCFA). The DCFA allows to simulate the entire life cycle of the photovoltaic system, from the acquisition date to the end of its life cycle, to evaluate the most probable market value by discounting the annual cash flows generated by the system. In particular, the paper proposes a procedure to determine the discount rate in an innovative manner through the combination of a conventional financial method (the Build up Approach) and the analytical method which makes recourse to the use of the ascending and descending influences that act, each with positive or negative sign, on the specific risk factors related to the photovoltaic investment. To obtain an objective appraisal of the discount rate, the theory of the ascending and descending influences has been applied in this specific case for the calculation of the risk premium. The percentage incidences of the ascending and descending influences, which influence the formation of the risks to which they refer, are determined through this study for all the intrinsic factors, which are part of the photovoltaic investment risks.
\end{abstract}

Keywords: ground mounted photovoltaic systems; Discounted Cash Flow Analysis; ascending and descending influences

\section{Introduction: Ground Mounted Photovoltaic Systems}

The increasing attention to environmental emergencies has produced substantial investments in the renewable energy sector and, in particular, in photovoltaic panels systems. The ground mounted photovoltaic systems are constituted by the photovoltaic panels which are installed on metal structures raised from the ground, suitably dimensioned and anchored through a point system of steel poles. These systems are connected to the grid, which facilitates the selling of all of the produced energy to the electricity companies. It is a technology which enables the production of so-called "renewable energy". The photovoltaic modules are oriented South to maximize electricity production. The energy production occurs through the conversion of solar radiation directly into electric energy. The photovoltaic cell is the basis element of the photovoltaic module and it is constituted by a semiconductor material, the silicon, which has an extremely reduced thickness $(0.3 \mathrm{~mm})$ and it is treated through an operation of "doping", which consists of treating the silicon with phosphorus and boron atoms, in order to obtain stable electrical currents within the cell. The photovoltaic module is formed by photovoltaic cells which are connected in series or parallel. The photovoltaic cells, which are put on the market, can be made with monocrystalline, polycrystalline or amorphous silicon. In photovoltaic systems, an important role is played by inverters, which convert the direct current of 
photovoltaic modules in alternating current grid and then, put it in the grid. Additionally, the inverters control and monitor the entire system; in fact, they ensure that the photovoltaic modules always operate at peak performance, in function of the irradiation and temperature, and constantly monitor the grid. The advantages arising from the use of photovoltaic systems are several:

- $\quad$ solar energy is an abundant and unlimited resource; in fact, the energy that the Earth receives from the Sun each hour is equal to the world's annual energy requirement;

- $\quad$ no $\mathrm{CO}_{2}$ emissions into the atmosphere during its operation; in fact, according to the International Energy Agency (IEA), photovoltaic systems [1], installed in 2013, generated 130 terawatt hours per year (TWh/year) of clean electricity, avoiding the emission of 140 million tons of $\mathrm{CO}_{2}$;

- $\quad$ presents a useful life of 30 years;

- $\quad$ more stable than wind turbines;

- $\quad$ quiet in operation;

- $\quad$ economically attractive, because it avoids both the import of fuel and energy dependency on fossil fuel;

- photovoltaic panels can be recycled at the end of their useful life;

- the silicon, which is used for the realization of the photovoltaic modules, is the second most abundant element in the Earth's crust.

From the Renewables 2015 Global Status Report, prepared by REN21 [2], it can be inferred that 2014 was a very important year for the photovoltaic market; in fact, there was a growth of $40 \mathrm{GW}$, reaching a total capacity of $177 \mathrm{GW}$. This has happened despite the decline of the European market. The main markets were China, Japan, the United States, Germany and Britain. According to IEA appraisals, presented in the report Solar Photovoltaic Energy Roadmap 2015, in 2050, photovoltaic-produced energy could cover $16 \%$ of the world's demand for electrical energy, with global installation, which could reach 4,600 GW and a production of about 6300 TWh per year.

These encouraging projections are mainly due to two reasons: the clean energy production to reduce global warming, and the lowering of costs for the construction of photovoltaic systems. According to the IEA the costs of large size photovoltaic systems will drop by $65 \%$ between 2015 and 2050 to reach EUR 545 per kilowatt installed [3].

This paper tackles the appraisal of the ground mounted photovoltaic system through the appraisal approach known as Discounted Cash Flow Analysis (DCFA). A critical point of the application of the DCFA for the appraisal of photovoltaic systems is the determination of the discount rate. The present study aims to solve the problem by creating a discount rate obtained by the combination of the Build-up Approach, and the analytical method in which the rate is obtained from a market rate, to which the increases and decreases are added.

\section{Literature Review}

The first scientific papers which have affected the evaluation of photovoltaic systems date back to the early 1980s [4,5]. These papers highlight that the most appropriate evaluation methodology to determine the most probable market value of the photovoltaic systems is the income capitalization approach, because it is not possible to find the sales data in the market for this particular type of real estate property. Another reason for discussing the use of the income capitalization approach in the evaluation of photovoltaic systems, is that this method is a financial method which takes into account the income to appraise any real estate. In fact, it must be considered that photovoltaic systems generate income during their life cycle. In these papers, the authors hesitate to recommend the income capitalization approach as the most suitable method to use without intervening in the methodology.

Since 2001 in the United States of America, the number of mounted photovoltaic systems has increased considerably, enough so, that the appraisers have had the problem of evaluating the market value of the properties characterized by energy saving arrangements [6-9], because there are no guidelines for the appraiser in this specific case. 
In 2010 the Appraisal Institute tried to implement the guidelines on evaluation methods with the text "An Introduction to Green Homes" [10]. In this text, authors highlight all the technical and economic characteristics which influence the market value of real estate that have photovoltaic systems. In 2012, the Sandia National Laboratories developed an electronic spreadsheet (PV Value Tool), which allows for the evaluation of the most probable market value of a photovoltaic system, using the income capitalization approach [11]. This evaluation tool is an excel spreadsheet that the appraiser can download for free and is based on the Discounted Cash Flow Analysis (DCFA). The appraised value depends on the energy produced by the photovoltaic system, the function of its geographical location, the power in Watts, the inclination of the modules, the operating expenses, the maintenance expenses, the expenses for the replacement of inverters and the age the photovoltaic system.

In 2014, the Italian Revenue Agency [12] gave the guidelines for the fiscal evaluation of the photovoltaic systems with the method of Discounted Cash Flow Analysis. In these guidelines it is recommended to determine the discount rate with an indirect method, because it is not possible to find the necessary data to determine it directly for the case of photovoltaic systems.

Currently, the major European photovoltaic markets are Germany, Italy, Spain and France [13,14]. Among these countries the feed-in-tariff contribution is currently present in Germany and France. In the countries where the feed-in-tariff contribution is present, the value of the photovoltaic systems is higher than those in the countries where the subsides are absent.

In recent years, the Italian photovoltaic market has decreased because of the closure of the feed-in-tariff contribution from the Italian Government. The feed-in-tariff represented a relevant income for the investors in renewable energy sources over the years. Despite this situation, the photovoltaic systems are nonetheless an economic benefit for investors. In this particular field, there are some studies which investigate the grid parity time and the levelized cost of energy of grid-connected photovoltaic systems installed [15]. To investigate the grid parity is very important in order to evaluate whether or not the photovoltaic systems are competitive with conventional grid-supplied electricity. The lack of the feed-in-tariff contribution determines the absence of the grid parity condition. The electricity produced by the photovoltaic systems is economically profitable and it is significantly influenced by the latitude of the region. For this reason, only the photovoltaic systems located in South regions are economically attractive to investors [16].

After the Italian feed-in-tariff ceased, it became necessary to evaluate the feasibility of unsubsidized photovoltaic systems. In this situation, economic methodologies able to evaluate the photovoltaic systems are represented by the Net Present Value, the Internal Rate of Return and the Discounted Payback Time. These financial indicators are based on the annual cash flow obtained from the differences between the annual revenue and costs generated during the lifetime of the investment $[17,18]$.

The authors Lazzeroni, Oliviero and Repetto [19], presented a methodology for the analysis of technical and economical photovoltaic systems through the Net Present Value. This economic approach depends on the following factors: the typology of the photovoltaic systems, yearly energy consumption, electric load profile, installed capacity, photovoltaic productivity and electricity grid costs.

Many international studies examine techno-economic analysis [20-24] for building integrated photovoltaics $[25,26]$.

Irrespective of the number of studies done, it is clear that the appraisal of a photovoltaic system requires an income approach, but as far as we know, there are no indications about the determination of the discounted rate able to consider the many parameters that affect it. In this work, we propose a way to appraise the capitalization rate for the application of the DCFA in the photovoltaic system, taking into account all the factors that contribute to the determination of the discounted rate.

\section{Methodology}

According to the International Valuation Standards (IVS), when the income aspect is relevant, the income approach may be used in order to evaluate the market value of a property. 
The income approach includes three procedures: the direct capitalization, the yield capitalization and discounted cash flow analysis (DCFA). Direct capitalization directly converts the income of a property in the market value, dividing the annual income for the capitalization rate. Yield capitalization converts future incomes in the present value of the property through a discount rate. The DCFA resumes the method of yield capitalization and considers both revenues and expenses which occur during the life of the photovoltaic system [27]. Unlike the yield capitalization, it allows to evaluate the current value of the properties in an intermediate time of the investment cycle. Among the three methods which are comprised in the income capitalization approach, the most suitable for the evaluation of a photovoltaic system is the Discounted Cash Flow Analysis (DCFA) for the following reasons:

- $\quad$ the reduced transparency of the acquisition market of photovoltaic systems, which makes it difficult to obtain the data relating to the sales and to the technical and production characteristics of the systems;

- photovoltaic systems are real estate investments with the capacity to generate cash flow during their life cycle;

- $\quad$ the ability of the method to evaluate the economic performance of the investment.

The DCFA is a method which allows for the appraisal of the present value of the photovoltaic system, discounting to the valuation date of the appraised future cash flow through the discount rate. The cash flows are generated annually throughout the duration of the investment and are given by the difference between the annual income and the annual operating expenses.

The DCFA allows for the simulation of the complete real estate investment cycle, from the entry into service of the photovoltaic system, until the date the life cycle finishes. Revenues of a photovoltaic system derive from government incentives, if they are present, and from the sale of energy produced in the free market. The revenues are influenced by the annual energy potentially producible by the photovoltaic system, which depends on the location of the system installation, the design features and the materials of which the photovoltaic modules are made. The operational expenditures are obtained through the sum of the fixed expenses, variables expenses and expenses for extraordinary maintenance.

The critical phase of the DCFA is represented by the determination of the discount rate because even small percentage variations of the discounted rate $(<0.005)$ reflect in significant variations in value. Therefore, the discount rate must be as accurate and reliable as possible and adequately justified.

The present study aims to solve this problem by proposing a procedure able to determine the discount rate, obtained by the combination of the Build-up Approach and the analytical method.

In this particular case, the Build-up Approach has been modified through the use of ascending and descending influences which act, each with positive or negative sign, in the formation of the discount rate.

The discount rate is obtained by the sum of the risk-free rate and the risk premium.

The risk-free rate is obtained assuming the yield of financial products characterized by minimum guaranteed yield.

The risk premium for a photovoltaic system is given by the sum of the risk context, the endogenous risk, the financial risk, the risk system, the insurable risk and the property risk management.

The percentage incidence of the ascending and descending influences are determined by taking into account the factors which contribute to the formation of the risks of photovoltaic investment such as: the geographical location of the photovoltaic system, the solar cell material, the photovoltaic system age, the tilt and orientation of the panels, the government incentives, etc.

In this way, it is possible to determine a more objective discount rate, because the use of the ascending and descending influences takes into account all of the circumstances which quantitatively influence the market. 


\subsection{The Discounted Cash Flow Analysis (DCFA)}

The DCFA is a valuation method which allows for the simulation of the entire life cycle of the photovoltaic system, from the acquisition date to the end of its life cycle, and is able to evaluate its current value by discounting the expected annual cash flow. The expected annual cash flows are derived from the difference between the revenues and the operating expenses, which are generated during the life cycle of the photovoltaic system. For the evaluation of solar fields, the DCFA comes in the following form:

$$
V=\sum_{t=1}^{n} \frac{\left(R_{t}-S_{t}\right)}{(1+k)^{t}}-\frac{V_{f}}{(1+k)^{s}}
$$

where:

$R_{t}$ : expected annual revenues ( $€ /$ year);

$S_{t}$ : expected annual operating expenses ( $€ /$ year);

$k$ : discount rate;

$V_{f}$ : final output value $(€)$;

$n$ : investment time horizon (years);

$s$ : year in which the system has to be dismantled (year);

$t$ : generic year (year).

In the discount method of expected annual cash flow, a critical point is the choice of the discount rate, which depends on the type of data that can be found in the market segment to which the subjects belong [28].

According to the Equation (1), the current value, which corresponds to the most probable market value of the subject, is obtained from the difference between the sum of the discounted cash flows and the final output value.

The expected annual revenues are generated by government incentives and the sale of produced energy, so that their quantification is related to the energy that the system produces according to its technical characteristics.

The expected annual operating expenses are generated by all the expenses which constitute the proper management of the photovoltaic system. The operating expenses are divided into fixed costs, variable costs and expenses for extraordinary maintenance.

The discount rate allows for the calculation of discounted cash flows. The calculation of the discount rate is the most important phase of this method, because the DCFA is based on the economic principle of anticipation. The discount rate can be directly determined from the market or through indirect methods such as the Build-up Approach, the expected return and the Weighted Average Cost of Capital (WACC).

The discount rate is obtained by the sum of the risk-free rate and the risk premium.

The risk-free rate is the interest rate of an activity without the default risk of the borrower and the risk of changes in market interest rates. So the risk-free rate is the return rate required by an investor. In real estate appraisals, this can be used as the risk-free rate of a government bond with a similar maturity to that of a considered temporal horizon. It is believed that during the considered temporal period, the property maintains its utility. The yield of the German Bunds, taken on the evaluation date, can be used as the risk free rate. Alternatively, in Italy, a good approximation is given by the gross yield of the Multi-Year Treasury Bonds (BTP) with maturity of 15 years [29,30].

The risk premium for a photovoltaic system is given by the sum of the risk context, the endogenous risk, financial risk, the risk of system, the insurable risk and the property risk management. The objective value of these risks is calculated by operating to their relative average theoretical risk deductions or additions resulting from the specific detected influences. The ascending influences increase the risk linked to the factor to which they refer, while the descending influences lessen the risk related to the factor to which they refer. The technical and economic characteristics of the subject 
determine the factors that are fundamental for the formation of risks related to the specific investment. For each of the factors, there are percentage incidences of the ascending and descending influences.

The final output value coincides with the photovoltaic systems of dismantling and soil restoration. In Equation (1), the final output value is considered only in the case where these costs are borne by the buyer.

\subsection{The Discount Rate}

A key point of DCFA is the determination of the discount rate, which allows for the determination of the present value of future cash flows generated by the PV system during its life cycle and its value.

The discount rate is directly determined from the market only in special circumstances of perfect competition, when the sales price or the lease price is known (Multilevel, Price Index).

When it is not possible to determine the discount rate by direct investigation of the market, because of not being able to obtain information about the flow of income and the market value of similar photovoltaic systems, it is possible to determine it indirectly, by analyzing the different circumstances which influence the discount rate quantitatively.

Among the indirect methods for determining the discount rate, there is the Build-up Approach, which is helpful for the fiscal evaluation of a photovoltaic system through the DCFA [12]. The discount rate is determined by the sum of the risk-free rate and the risk premium, which considers the general or specific components of the risks which constituted it. The equation to determine the discount rate with the Build-Up Approach is the following:

$$
K=K_{f}+P R
$$

where:

$K$ : discount rate;

$K_{f}$ : risk-free rate;

$P R$ : risk premium.

The risk-free rate can coincide with the yield of the German Bunds, considered to the valuation date, or with the yield of the Multi-year Treasury Bonds (BTP), the duration of which is homogeneous to the duration of the investment.

The risk premium depends on the photovoltaic investment and it takes into account the following risks:

(a) the financial risk is related to fluctuations in inflation, the non-liquidity of real estate and the degree of leverage;

(b) the system risk is related to changes in the economic, political, regulatory, administrative and environmental scene. It corresponds to the spread between Treasury Bonds (BTP) and German Bunds on the valuation date;

(c) the business risk takes into account the general risks of the real estate investment and the risks related to the specificities of the subject.

We propose the use of the Build-up Approach, by resorting to the method of ascending and descending influences $[31,32]$ to determine the capitalization rate for urban real estate investments. The Italian appraiser Carlo Forte reckoned that the variation points between the minimum and maximum rate can be determined by a number of ascending or descending influences that act, each with a positive sign (ascendant) or negative sign (descendants), on the average rate [33]. Then, the capitalization rate is obtained starting from the average rate, evaluated for urban investment, operating deductions and additions resulting from specific detected influences:

$$
r=r_{m}+\sum_{i=1}^{18} A_{i}-\sum_{i=1}^{18} D_{i}
$$


where:

$r$ : capitalization rate of the urban investment;

$r_{m}$ : average rate of the real estate investment;

$A_{i}$ : ascending influences;

$D_{i}$ : descendants influences.

The percentage incidences of the ascending and descending influences on the capitalization rate are synthetically determined through the comparative experiences of the market.

In order to indirectly determine the most probable discount rate for the appraisal of a ground mounted photovoltaic system through the DCFA, the Build-up Approach has been integrated with the Forte method of ascending and descending influences.

All the risks which constitute the risk premium are determined, taking into account the ascending and descending influences of the various intrinsic factors that are part of the risk.

The risk premium, which is given by the sum of the different risk aliquots, can be written according to the following equation:

$$
P R=R_{\text {cont }}+R_{\text {end }}+R_{\text {fin }}+R_{\text {sist }}+R_{\text {ass }}+R_{\text {gest }}
$$

The types of risk associated with the investment of the photovoltaic systems are:

- the risk context $\left(R_{\text {cont }}\right)$ is a risk linked to the geographical location of the photovoltaic system in the country and in relation to the presence of shaded areas caused by natural obstacles or inclination of the panels;

- the endogenous risk $\left(R_{\text {end }}\right)$ is a risk linked to the technical characteristics of the photovoltaic system, which influence the energy performance, and the purchase of electricity prices;

- the financial risk $\left(R_{\text {fin }}\right)$ is a risk linked to the specific investment;

- $\quad$ the risk system $\left(R_{\text {sist }}\right)$ is a risk that manifests itself in the national market level at which the system is inserted. It refers to changes in the normative and fiscal scene, which can influence the revenues that are generated from the selling of the energy produced, and the feed-in-tariff contribution;

- the insurable risk $\left(R_{a s s}\right)$ is a risk associated with the possibility that external events of particular gravity, like theft and natural disasters, can cause damage to the solar modules that can affect the correct production of the photovoltaic system. So the investor can protect against this risk by taking out an insurance policy. This type of risk is linked to the onerousness of the insurance policy;

- the property risk management $\left(R_{\text {gest }}\right)$ is a risk linked to the property management of the photovoltaic system by the investor. In order for the system to generate positive operating cash flows with respect to the expectations of the investors, the ordinary and extraordinary repairs are very important. This type of operation is used to program the physical depreciation of value over time and to obtain the expected production of energy.

For the range in which the listed risks fall, it can take as a reference the Table 1 of risks [26], which was implemented for the particular case of photovoltaic systems.

Table 1. Risk factors of the photovoltaic investment.

\begin{tabular}{ccc}
\hline Typology of Risk & Range (\%) & $\boldsymbol{R}_{\text {taverage }} \mathbf{( \% )}$ \\
\hline Context risk & $0.25-2.50$ & 1.38 \\
Endogenous risk & $0.30-2.00$ & 1.15 \\
Financial risk & $0.50-1.50$ & 1.00 \\
Risk system & $0.50-2.00$ & 1.25 \\
Insurable risk & $0.20-1.00$ & 0.60 \\
Property risk management & $0.20-1.00$ & 0.60 \\
Total & & 5.98 \\
\hline
\end{tabular}


The risk expresses the probability that the specific yield, tied to it, cannot be realized. The risks are influenced by a series of conditions relating to various factors, which exert the ascending and descending influences.

For each type of risk, the average theoretical risk $\left(R_{\text {taverage }}\right)$ has been determined. It represents the average percentage of risk to which it will have to operate the deductions and additions deriving from the specific influences, expressed in the percentage, identified by the analysis of the various factors that influence it for that particular type of risk. So the percentage incidence of the risks listed in the table can be obtained with the following equation:

$$
R_{i}=R_{\text {taverage }}+\sum_{i=1}^{n} A_{i}-\sum_{i=1}^{n} D_{i}
$$

where:

$R_{i}$ : generic risk;

$R_{\text {taverage: }}$ theoretical average risk;

$A_{i}$ : ascending influences, which act with a positive sign on the average theoretical risk. They increase the risk of the factor to which it relates in a given circumstance;

$D_{i}$ : descending influences, which act with a negative sign on the average theoretical risk. They diminish the risk of the factor to which it relates in a given circumstance.

As a result, the risk premium can be expressed through the following equation:

$$
P R=\sum_{i=1}^{m} R_{i}=\sum_{i=1}^{m}\left(R_{\text {taverage }}+\sum_{i=1}^{n} A_{i}-\sum_{i=1}^{n} D_{i}\right)
$$

The ascending and descending influences are reported Tables 2-6.

Table 2. Ascending and descending influences for the risk context.

\begin{tabular}{ccc}
\hline Risk Typology & Factors & $\begin{array}{c}\text { Ascending Influences (+) and } \\
\text { Descending Influences (-) }\end{array}$ \\
\hline Geographical location of the \\
system \\
South Italy \\
Centre Italy \\
North Italy
\end{tabular}

Table 3. Ascending and descending influences for the endogenous risk.

\begin{tabular}{ccc}
\hline Risk Typology & Factors & $\begin{array}{c}\text { Ascending Influences (+) and } \\
\text { Descending Influences (-) }\end{array}$ \\
\hline & Nominal power of the system $(\mathrm{kW})$ & $+0.30 \%$ \\
Small size $(\mathrm{P}<100 \mathrm{~kW})$ & $-(0.20 \div 0.40) \%$ \\
Eedium size $(100 \mathrm{~kW} \leq \mathrm{P} \leq 1000 \mathrm{~kW})$ & $-(0.50 \div 1.00) \%$ \\
Large size $(\mathrm{P}>1000 \mathrm{~kW})$ & $-0.25 \%$ \\
Solar cell material & $-0.20 \%$ \\
& Monocrystalline silicon & $-0.05 \%$ \\
Polycrystalline silicon & Amorphous silicon & $+(0.15 \div 0.30 \%$ \\
& Age of the system & $\pm 0.10 \%$ \\
\hline
\end{tabular}


Table 4. Ascending and descending influences for the risk system.

\begin{tabular}{ccc}
\hline Risk Typology & Factors & $\begin{array}{c}\text { Ascending Influences (+) and } \\
\text { Descending Influences (-) }\end{array}$ \\
\hline & Government Incentives & \\
& I feed-in-tariff contribution & $-0.45 \%$ \\
Financial risk $\left(R_{\text {fin }}\right)$ & II feed-in-tariff contribution & $-0.35 \%$ \\
& III feed-in-tariff contribution & $-0.30 \%$ \\
& IV feed-in-tariff contribution & $-0.20 \%$ \\
& V feed-in-tariff contribution & $-0.10 \%$ \\
& None feed-in-tariff contribution & $+0.30 \%$ \\
\hline \multirow{2}{*}{ Risk system $\left(R_{\text {sist }}\right)$} & Quotes of the investment returns & $\pm 0.50 \%$ \\
\hline
\end{tabular}

Table 5. Ascending and descending influences for the insurable risk.

\begin{tabular}{ccc}
\hline Risk Typology & Factors & $\begin{array}{c}\text { Ascending Influences (+) and } \\
\text { Descending Influences (-) }\end{array}$ \\
\hline \multirow{2}{*}{ Insurable risk $\left(R_{\mathrm{ass}}\right)$} & Power of the system & $+(0.10 \div 0.35) \%$ \\
& Disaster risk & $+(0 \div 0.20) \%$ \\
& Theft risk & $+(0.10 \div 0.40) \%$ \\
\hline
\end{tabular}

Table 6. Ascending and descending influences for the property risk management.

\begin{tabular}{ccc}
\hline Risk Typology & Factors & $\begin{array}{c}\text { Ascending Influences (+) and } \\
\text { Descending Influences (-) }\end{array}$ \\
\hline Property risk management $\left(R_{\text {gest }}\right)$ & Repairs & $-0.30 \%$ \\
& Periodical & Non periodic \\
Reliability of the SGR & $+(0.50 \div 2.00) \%$ \\
\end{tabular}

\section{Case Study}

The photovoltaic system located in Calabria (Southern Italy) has a peak power of $983.60 \mathrm{kWp}$. Photovoltaic panels are installed on raised metal structures, suitably dimensioned and anchored through a point-shaped steel pole system. All the energy produced the system is sold to electric companies. The subject's characteristics are shown in Table 7.

Table 7. Photovoltaic system's characteristics.

\begin{tabular}{cc}
\hline System Size-Peak Power & $983.60 \mathrm{~kW}$ \\
\hline Module tecnhology & polycrystalline \\
System age & 4 years \\
System's Remaining Energy & 21 years \\
System Losses & $25 \%$ \\
Mounting position & ground mounted system \\
Slope & $35^{\circ}$ \\
Azimuth & $180^{\circ}$ \\
Annual energy potentially producible by the system & $1,250.000 \mathrm{kWh}$ \\
Feed-in-tariff contribution & $\mathrm{IV}$ \\
\hline
\end{tabular}

On the basis of the technical characteristics of the system (Table 1) and by using a photovoltaic simulation software (PVGIS simulator, made available by the European Commission Joint Research Center), we have calculated the monetary revenues from the feed-in-tariff contribution and those generated by the sale of energy in the free market (Table 8). 
Table 8. Total expected revenues of the photovoltaic system.

\begin{tabular}{ccccc}
\hline Year & $\begin{array}{c}\text { Production Taken } \\
\text { from the Reference } \\
\text { Date (kWh) }\end{array}$ & $\begin{array}{c}\text { Incentive from the IV } \\
\text { Feed in Tariff } \\
\text { Contribution }(\boldsymbol{\ell} / \mathbf{k W h})\end{array}$ & $\begin{array}{c}\text { Purchase Prices } \\
\text { Projection } \\
\mathbf{(} / \mathbf{k W h})\end{array}$ & $\begin{array}{c}\text { Total Revenues } \\
\text { (Incentives }+ \\
\text { Purchase) }(\boldsymbol{(})\end{array}$ \\
\hline 2016 & $1,188,495.00$ & 0.155 & 0.0620 & $257,874.24$ \\
2017 & $1,176,367.50$ & 0.155 & 0.0614 & $254,607.26$ \\
2018 & $1,164,240.00$ & 0.155 & 0.0609 & $251,353.39$ \\
2019 & $1,152,112.50$ & 0.155 & 0.0604 & $248,112.62$ \\
2020 & $1,139,985.00$ & 0.155 & 0.0598 & $244,884.96$ \\
2021 & $1,127,857.50$ & 0.155 & 0.0593 & $241,670.40$ \\
2022 & $1,115,730.00$ & 0.155 & 0.0587 & $238,468.95$ \\
2023 & $1,103,602.50$ & 0.155 & 0.0582 & $235,280.61$ \\
2024 & $1,091,475.00$ & 0.155 & 0.0577 & $232,105.36$ \\
2025 & $1,079,347.50$ & 0.155 & 0.0571 & $228,943.23$ \\
2026 & $1,067,220.00$ & 0.155 & 0.0566 & $225,794.20$ \\
2027 & $1,055,092.50$ & 0.155 & 0.0560 & $222,658.27$ \\
2028 & $1,042,965.00$ & 0.155 & 0.0555 & $219,535.45$ \\
2029 & $1,030,837.50$ & 0.155 & 0.0550 & $216,425.74$ \\
2030 & $1,018,710.00$ & 0.155 & 0.0544 & $213,329.13$ \\
2031 & $1,006,582.50$ & 0.155 & 0.0539 & $210,245.63$ \\
2032 & $884,220.62$ & 0.155 & 0.0533 & $184,210.05$ \\
\hline
\end{tabular}

Operating expenses are obtained through the sum of fixed costs, variable costs and overtime costs (Table 9).

Table 9. Total operating costs.

\begin{tabular}{cccccc}
\hline Year & $\begin{array}{c}\text { Municipal Tax on } \\
\text { the Property } \\
\text { (In Italy IMU (€)) }\end{array}$ & $\begin{array}{c}\text { Insurance } \\
\text { Policy }(\boldsymbol{(})\end{array}$ & $\begin{array}{c}\text { Expenses for Administration, } \\
\text { Maintenance and Utilities (€) }\end{array}$ & $\begin{array}{c}\text { Extraordinary } \\
\text { Maintenance } \\
\text { Costs }(\boldsymbol{(})\end{array}$ & $\begin{array}{c}\text { Total } \\
\text { Costs }(\boldsymbol{€})\end{array}$ \\
\hline 2016 & $18,738.72$ & 7868.80 & $59,344.00$ & $50,000.00$ & $135,951.52$ \\
2017 & $19,207.19$ & 8104.86 & $60,827.60$ & $50,000.00$ & $138,139.65$ \\
2018 & $19,687.37$ & 8348.01 & $62,348.29$ & $50,000.00$ & $140,383.67$ \\
2019 & $20,179.55$ & 8598.45 & $63,907.00$ & $50,000.00$ & $142,685.00$ \\
2020 & $20,684.04$ & 8856.40 & $65,504.67$ & $50,000.00$ & $145,045.12$ \\
2021 & $21,201.14$ & 9122.10 & $67,142.29$ & $50,000.00$ & $147,465.53$ \\
2022 & $21,731.17$ & 9395.76 & $68,820.85$ & $50,000.00$ & $149,947.78$ \\
2023 & $22,274.45$ & 9677.63 & $70,541.37$ & $50,000.00$ & $152,493.45$ \\
2024 & $22,831.31$ & 9967.96 & $72,304.90$ & & $105,104.17$ \\
2025 & $23,402.09$ & $10,267.00$ & $74,112.52$ & & $107,781.62$ \\
2026 & $23,987.15$ & $10,575.01$ & $75,965.34$ & & $110,527.49$ \\
2027 & $24,586.82$ & $10,892.26$ & $77,864.47$ & & $113,343.55$ \\
2028 & $25,201.50$ & $11,219.03$ & $79,811.08$ & & $116,231.60$ \\
2029 & $25,831.53$ & $11,555.60$ & $81,806.36$ & & $119,193.49$ \\
2030 & $26,477.32$ & $11,902.27$ & $83,851.52$ & & $122,231.11$ \\
2031 & $27,139.25$ & $12,259.33$ & $85,947.81$ & & $125,346.39$ \\
2032 & $22,616.05$ & $10,216.11$ & $710,623.17$ & & $104,455.33$ \\
\hline
\end{tabular}

After determining actual revenue and operating expenses, one can determine the expected cash flow by calculating the difference between total revenue and total expense for each year (Table 10). 
Table 10. Expected cash flow.

\begin{tabular}{cccc}
\hline Year & Total Revenues $(\boldsymbol{\epsilon})$ & Total Costs $(\boldsymbol{\ell})$ & Expected Cash Flow $(\boldsymbol{€})$ \\
\hline 2016 & $257,874.24$ & $135,951.52$ & $121,922.72$ \\
2017 & $254,607.26$ & $138,139.652$ & $116,467.61$ \\
2018 & $251,353.39$ & $140,383.6676$ & $110,969.72$ \\
2019 & $248,112.62$ & $142,684.9994$ & $105,427.62$ \\
2020 & $244,884.96$ & $145,045.1166$ & $99,839.84$ \\
2021 & $241,670.40$ & $147,465.5265$ & $94,204.88$ \\
2022 & $238,468.95$ & $149,947.7752$ & $88,521.18$ \\
2023 & $235,280.61$ & $152,493.4483$ & $82,787.16$ \\
2024 & $232,105.36$ & $105,104.1727$ & $127,001.19$ \\
2025 & $228,943.23$ & $107,781.6168$ & $121,161.61$ \\
2026 & $225,794.20$ & $110,527.4922$ & $115,266.71$ \\
2027 & $222,658.27$ & $113,343.5546$ & $109,314.72$ \\
2028 & $219,535.45$ & $116,231.6048$ & $103,303.85$ \\
2029 & $216,425.74$ & $119,193.49$ & $97,232.25$ \\
2030 & $213,329.13$ & $122,231.1053$ & $91,098.02$ \\
2031 & $210,245.63$ & $125,346.3942$ & $84,899.23$ \\
2032 & $184,210.05$ & $104,455.325$ & $79,754.73$ \\
\hline
\end{tabular}

For the appraisal of the market value of the photovoltaic system, cash flows need to be discounted at an appropriate rate. In the conventional appraisal, the Build Up approach refers to the sum of financial risk, system risk and business risk (Equation (2)). The contribution of risk components is valuated on the basis of the Tax Office directions [12] and are shown in Table 11.

Table 11. Financial risk.

\begin{tabular}{cccc}
\hline Financial Risk & System Risk & Business Risk & Total \\
\hline $0.50 \%$ & $1.04 \%$ & $1.00 \%$ & $2.54 \%$ \\
\hline
\end{tabular}

According to the conventional appraisal, the discount rate is $3.12 \%$.

Using the method proposed in the present paper, based on the use of ascending and descending influences, the discount rate calculated takes into account the specifics of the photovoltaic system, its technical characteristics and the geographical, territorial and economic contour conditions.

The results, shown in Table 12, are derived from the tables indicated in the text (from Tables 1-6).

Table 12. Risks calculated with the theory of influences.

\begin{tabular}{cccc}
\hline Risk Typology & $\begin{array}{c}\text { Average Teoric Risk } \\
\left(\mathbf{R}_{\text {taverage }}\right)\end{array}$ & $\begin{array}{c}\text { Ascending Influences } \\
\left(+\sum_{i=\mathbf{1}}^{n} A_{\boldsymbol{i}}\right)\end{array}$ & $\begin{array}{c}\text { Descending Influences } \\
\left(-\sum_{i=\mathbf{1}}^{n} \boldsymbol{D}_{\boldsymbol{i}}\right)\end{array}$ \\
\hline Context risk & $1.38 \%$ & - & $-1.10 \%$ \\
Endogenous risk & $1.15 \%$ & $+0.15 \%$ & $-0.70 \%$ \\
Financial risk & $1.00 \%$ & - & $-0.20 \%$ \\
Risk system & $1.25 \%$ & - & $-0.50 \%$ \\
Insurable risk & $0.60 \%$ & $-0.85 \%$ & - \\
Property risk & $0.60 \%$ & - & $-0.50 \%$ \\
management & $P R=\sum_{i=1}^{n} R_{i}$ & & $3.98 \%$ \\
& &
\end{tabular}

Discounted rate (see Table 13) is obtained using Equation (2). 
Table 13. Discounted rate.

\begin{tabular}{ccc}
\hline Risk-Free Rate $\left(\mathbf{K}_{\mathbf{f}}\right)$ - (Equal to German Bund) & Risk Premium (PR) & Total \\
\hline $0.59 \%$ & $3.98 \%$ & $4.57 \%$ \\
\hline
\end{tabular}

Once the discount rate is calculated, the market value of the photovoltaic system is calculated by discounting net revenues:

$$
\mathrm{V}=\sum_{\mathrm{t}=1}^{\mathrm{n}} \frac{\left(\mathrm{R}_{\mathrm{t}}-\mathrm{S}_{\mathrm{t}}\right)}{(1+\mathrm{k})^{\mathrm{t}}}
$$

Results are shown in Table 14.

Table 14. Discounted cash flow.

\begin{tabular}{|c|c|c|c|}
\hline Year & Expected Cash Flow $(€)$ & Coefficient of Discounting $\left(1 / q^{t}\right)$ & Discounted Cash Flow $(€)$ \\
\hline 2016 & $121,922.72$ & 0.956297217 & $116,594.36$ \\
\hline 2017 & $116,467.61$ & 0.914504368 & $106,510.14$ \\
\hline 2018 & $110,969.72$ & 0.874537982 & $97,047.24$ \\
\hline 2019 & $105,427.62$ & 0.836318238 & $88,171.04$ \\
\hline 2020 & $99,839.84$ & 0.799768804 & $79,848.79$ \\
\hline 2021 & $94,204.88$ & 0.764816682 & $72,049.46$ \\
\hline 2022 & $88,521.18$ & 0.731392064 & $64,743.69$ \\
\hline 2023 & $82,787.16$ & 0.699428196 & $57,903.67$ \\
\hline 2024 & $127,001.19$ & 0.668861237 & $84,946.17$ \\
\hline 2025 & $121,161.61$ & 0.63963014 & $77,498.62$ \\
\hline 2026 & $115,266.71$ & 0.611676523 & $70,505.94$ \\
\hline 2027 & $109,314.72$ & 0.584944556 & $63,943.05$ \\
\hline 2028 & $103,303.85$ & 0.559380852 & $57,786.19$ \\
\hline 2029 & $97,232.25$ & 0.534934352 & $52,012.87$ \\
\hline 2030 & $91,098.02$ & 0.511556232 & 46.601 .76 \\
\hline 2031 & $84,899.23$ & 0.489199801 & $41,532.69$ \\
\hline 2032 & $79,754.73$ & 0.467820408 & $37,310.89$ \\
\hline \multicolumn{3}{|c|}{ Most probable market value (V) } & $1,215,006.58 €$ \\
\hline
\end{tabular}

The most probable market value of the photovoltaic system is $1,215,006.58 €$.

\section{Conclusions}

The present study addresses the economic appraisal of ground mounted photovoltaic systems through the procedure known as Discounted Cash Flow Analysis (DCFA), which allows for the appraisal of the most probable market value, by discounting annual expected cash flows generated from the system during its life cycle.

The innovation introduced by this study is to determine the discount rate through the combination of the Build Up Approach and the analytical method that makes use of the theory of ascending and descending influences.

In particular, the ascending influences act with a positive sign on the average theoretical risk, increasing the risk related to the factor to which they refer, while the descendants influences act as a negative on the average theoretical risk, decreasing the risk of the factor to which they refer.

For all the factors referable to the photovoltaic investment risks, we have determined the percentages of the ascending and descending influences that influence the formation of the risks to which they refer. The percentages are synthetically determined taking into account all the circumstances which quantitatively influence the market and every feature that influence the final value of the photovoltaic system.

The risks are influenced by a series of factors such as the geographic location of the photovoltaic system and the presence of shaded areas, the nominal power of the system, the solar cell material, the 
age of the system, the tilt and orientation of the photovoltaic modules and the efficiency of the system, the presence/absence of the feed-in-tariff contribution, the risk related to disasters and the theft risk, the maintenance and the reliability of the system administrator.

The proposed approach has a procedural and theoretical-methodological nature. No application has been proposed because the use of the proposed indices is strictly connected to the specific conditions of the photovoltaic system in question and cannot be generalized. The aim of the proposed approach is to provide a method, schemas and benchmarks for an objective determination of the discount rate in the appraisal of photovoltaic systems, by providing a detailed list of parameters to be considered and the percentages of ascending and descending influences to be applied in the specific appraising case.

Author Contributions: This paper is to be attributed in equal parts to the four authors.

Conflicts of Interest: The authors declare no conflict of interest.

\section{References}

1. Renewable Energy Policy Network for the 21st Century (REN21). Annual Reporting on Renewables: Ten Years of Excellence; REN21: Paris, France, 2015; ISBN 978-3-9815934-6-4.

2. International Energy Agency. World Energy Outlook 2015; OECD/IEA: Paris, France, 2015.

3. International Energy Agency. Technology Roadmap. Solar Photovoltaic Energy; OECD/IEA: Paris, France, 2014.

4. Webb, J.R. The influence of solar Energy systems on the value of dwellings: Theory vs. practice. Real Estate Apprais. Anal. 1980, 4-6.

5. Harris, J. The value of solar energy: Chic, patriotism and economic rationality. Real Estate Apprais. Anal. 1984, 5-7

6. Salvo, F.; Piro, P.; Nigro, G.; De Ruggiero, M. Economic Appraisal Model of Green Roofs in Residential Buildings; Valori e Valutazioni: Roma, Italy, 2017; in print.

7. De Ruggiero, M.; Forestiero, G.; Manganelli, B.; Salvo, F. Buildings Energy Performance in a Market Comparison Approach. Buildings 2017, 7, 16. [CrossRef]

8. Ietto, F.; Salvo, F.; Cantisano, N. The quality of life conditioning with reference to the local environmental management: A pattern in Bivona country (Calabria, Southern Italy). Ocean Coast. Manag. 2014, 102, 340-349. [CrossRef]

9. Ietto, F.; Salvo, F. Methodological approach for the evaluation of the sustainability of man made environments. Rend. Online Soc. Geol. Ital. 2012, 21, 759-760.

10. Simmons, A.F. An Introduction to Green Homes; Appraisal Institute: Chicago, IL, USA, 2010; ISBN 978-1-935328-09-4.

11. Klise, G.T.; Johnson, J.L.; Adomatis, S.K. Valuation of solar photovoltaic systems using a Discounted Cash Flow Approach. Apprais. J. 2013, 18, 316-331.

12. Agenzia delle Entrate Quaderni dell'Osservatorio. Appunti di economia immobiliare, Osservatorio del Mercato Immobiliare.Anno II, Numero 2. 2014. Available online: http://www.agenziaentrate.gov.it/ wps/file/Nsilib/Nsi/Documentazione/omi/Pubblicazioni/Quaderni+Osservatorio/Quaderni+dell+ Osservatorio+dicembre+2013/Quaderni_Anno_II_N_2_Dic_2013.pdf (accessed on 20 September 2016).

13. De Boeck, L.; Van Asch, S.; DeBruecker, P.; Audenaert, A. Comparison of support policies for residential photovoltaic systems in the major EU markets through investment profitability. Renew. Energy 2016, 87, 42-53. [CrossRef]

14. Campoccia, A.; Dusonchet, L.; Telaretti, E.; Zizzo, G. An analysis of feed-in-tariff for solar PV in six representative countries of the European Union. Solar Energy 2014, 107, 530-542. [CrossRef]

15. Orioli, A.; Di Gangi, A. Six-years-long effects on the Italian policies for photovoltaics on the grid parity of grid-connected photovoltaic systems installed in urban contexts. Energy 2017, 130, 55-75. [CrossRef]

16. Orioli, A.; Franzitta, V.; Di Gangi, A.; Foresta, F. The recent change in the Italian policies for photovoltaics: Effects on the energy demand coverage of grid-connected PV systems installed in urban context. Energies 2016, 9, 1-31. [CrossRef]

17. Squatrito, R.; Sgroi, F.; Tudisca, S.; Di Trapani, A.M.; Testa, R. Post feed-in scheme photovoltaic systems feasibility evaluation in Italy: Sicilian case studies. Energies 2014, 7, 7147-7165. [CrossRef] 
18. Cucchiella, F.; D'Adamo, I.; Rosa, P. Industrial photovoltaic systems: An economic analysis in non-subsidized electricity markets. Energies 2015, 8, 12865-12880. [CrossRef]

19. Lazzeroni, P.; Olivero, S.; Repetto, M. Economic perspective for PV under new Italian regolatory framework. Renew. Sustain. Energy Rev. 2017, 71, 283-295. [CrossRef]

20. Shaahid, S.M.; El-Amin, I. Techno-economic evaluation of off-grid hybrid photovoltaic-diesel-battery power systems for rural electrification in Saudi Arabia-A way forward for sustainable development. Renew. Sustain. Energy Rev. 2009, 13, 625-633. [CrossRef]

21. Kolhe, M. Techno-economic optimum sizing of a stand-alone solar photovoltaic system. IEEE Trans. Energy Convers. 2009, 24, 511-519. [CrossRef]

22. Hrayshat, E.S. Techno-economic analysis of autonomous hybrid photovoltaic-diesel-battery system. Energy Sustain. Dev. 2009, 13, 143-150. [CrossRef]

23. Chouder, A.; Silvestre, S.; Sadaoui, N.; Rahamani, L. Modeling and simulation of a grid connected PV system based on evaluation of main PV module parameters. Simul. Modell. Pract. Theory 2012, 20, 46-58. [CrossRef]

24. Hong, T.; Koo, C.; Park, J.; Seon Park, H. A GIS (geographic information system)-based optimization model for estimating the electricity generation of the rooftop PV (photovoltaic) system. Energy 2014, 65, 190-199. [CrossRef]

25. Hammond, G.P.; Harajli, H.A.; Jones, C.I.; Winnett, A.B. Whole systems appraisal of a UK Building Integrated Photovoltaic (BIPV) system: Energy, environmental, and economic evaluations. Energy Policy 2012, 40, 219-230. [CrossRef]

26. Oliver, M.; Jackson, T. Energy and economic evaluation of building-integrated photovoltaics. Energy 2001, 26, 431-439. [CrossRef]

27. Simonotti, M. Valutazione Immobiliare Standard; Stimatrix: Mantova, Italy, 2013; ISBN 978-88-904764-5-7.

28. Simonotti, M. Metodi di Stima Immobiliare; Dario Flaccovio Editore: Palermo, Italy, 2006; ISBN 88-7758-686-5.

29. Hoesli, M.; Morri, G. Investimento Immobiliare. Mercato, Valutazione, Rischio e Portafogli; Hoepli: Milan, Italy, 2015; pp. 121-138, ISBN 978-88-203-4387-3.

30. Betti, F. La Metodologia del DCFA Nella Pratica Professionale; Ordine Degli Ingegneri Della Provincia di Roma: Roma, Italy, 2016.

31. Forte, C.; Dè Rossi, B. Princìpi di Economia ed Estimo; Etaslibri: Milano, Italy, 1974; pp. 144-154.

32. D'Agostino, A. I Procedimenti di Stima Sintetici Indiretti; Geopunto: Roma, Italia, 2008; pp. 14-20.

33. D'Agostino, A. Estimo Immobiliare Urbano ed Elementi di Economia; Editrice Esculapio: Bologna, Italia, 2008. 